\title{
RAFAEL LAPESA, HISTORIADOR DE LA LENGUA
}

\author{
José Jesús de Bustos Tovar
}

\section{LINGÜÍSTICA HISTÓRICA E HISTORIA DE LA LENGUA.}

Rafael Lapesa es probablemente, el último y más ilustre miembro de la escuela de filología española, que fundara don Ramón Menéndez Pida!. Quiere esto decir que parte de los principios teóricos y metodológicos postulados por el maestro y sobre ellos ha construido toda su obra científica. Sin embargo, lejos de un servilismo doctrinal que lo hubiera convertido en un mero epígono, Lapesa ha desarrollado temas que apenas habían sido esbozados por Menéndez Pida! (como la descripción del proceso de apócope de la -e, el principio de la confusión fonológica de las sibilantes a partir del siglo XV, el estudio de los fueros primitivos, etc.), inició otros que apenas habían aparecido en la obra pidalina (la sintaxis histórica, de manera especial) y abordó campos del saber filológico y literario con metodología muy personal, como son sus numerosos análisis literarios de autores que abarcan desde las edad media hasta nuestros días. Esto es, Rafael Lapesa no se ha limitado a ser un mero continuador, sino que ha emprendido nuevas tareas, aunque, eso sí, manteniendo su fidelidad a la escuela filológica en la que se había formado

Partiendo del positivismo historicista, que es raíz común de todos los integrantes de la escuela de Menéndez Pida!, Lapesa, ha incorporado ideas de otras procedencias. En él han influido de manera notable, entre otros, Américo Castro, a quien debe la sugerencia para elaborar una sintaxis histórica, Amado Alonso, que se hizo eco del neoidealismo vossleriano, y también Dámaso Alonso, su "hermano mayor" del grupo filológico español, de quien admiró, entre otras cosas, la finura de su análisis estilístico. Se reúnen, pues, en Lapesa intereses científicos confluyentes, presididos siempre por una concepción de la historia en la que los cambios lingüísticos se explican por la interdependencia entre hechos de cultura y fenómenos sociales ${ }^{1 .}$

Si hubiera que sintetizar muy brevemente las ideas de Lapesa en el plano lingüístico, yo las resumiría del siguiente modo: $1^{\circ}$ ) la evolución lingüística se explica en primer término por razones internas a la propia lengua, sin que ello implique determinismo alguno. De este modo, Lapesa se identifica con Menéndez Pida!, en la idea de que los cambios lingüísticos constituyen tendencias evolutivas de carácter general que contienden entre sí y que se propagan mediante procesos en los que intervienen factores que atañen a la vida social; $2^{\circ}$ )

\footnotetext{
${ }^{1}$ Véase Lapesa, Rafael, Historia lingüistica e historia general, Discurso inaugural de la Secc. VII del XXIV Congreso Luso-Español para el Progreso de las Ciencias, pronunciado en Madrid el 14 de noviembre de 1958, Madrid, 1959. Nueva edición en Buscad sus pares, pocos, Madrid, Gredos, 1978, págs. 13-24.
} 
la escritura y, de modo especialmente relevante, la literatura, refleja de modo bastante fiel la consolidación de los fenómenos evolutivos; por tanto, los testimonios literarios, debidamente valorados en función de tales y también como manifestaciones del uso común, son una fuente privilegiada para el estudio de la historia lingüística; $3^{\circ}$ ) la historia de la lengua es, en cierto sentido, una parte de la historia de los pueblos que la hablan; existe, o puede existir, una correlación entre la descripción de los procesos evolutivos y la historia general de los pueblos. Esta afirmación hay que interpretarla al margen de una concepción idealista del lenguaje, ya que está basada siempre en la rigurosa documentación de los testimonios utilizados. No quiero decir con ello que Lapesa no haya recogido una cierta herencia idealista, sino que la ha tamizado pasándola por el filtro riguroso de un positivismo no materialista, aprendido en la escuela pidalina. Un ejemplo especialmente relevante de esta idea se halla explicado en su concepción de forma interior del lenguaje ${ }^{2}$, definido como proceso mediante el cual la historia de la comunidad social aprovecha ciertas tendencias evolutivas para plasmar en ellas una especial visión de la realidad.

Ya en su tesis doctoral sobre el Fuero de Avilés $^{3}$ se advierte la dirección que habían de seguir los trabajos de historia lingüística del profesor Lapesa. La inmigración de gentes procedentes de Francia, su asentamiento en barrios propios en distintas villas y el papel profesional que desempeñaron, así como su importante aportación en el ámbito económico, determinó la aparición de fuertes influencias lingüísticas, tal como se advierte en diversas fuentes jurídicas de la alta edad media ${ }^{4}$. Los trabajos de historia lingüística de Lapesa no son en sentido estricto, tal como hoy lo entenderíamos, estudios sociolingüísticos, pero todas las explicaciones de los fenómenos de cambio están referidos casi siempre a factores sociales. Un ejemplo paradigmático lo constituye su descripción del proceso que afecta a la apócope de la vocal final: los factores de naturaleza interna (estructura silábica, ritmo acentual, pérdida de vocales intertónicas, etc.), que algunos habían propuesto como explicación exclusiva del largo proceso de cambio ${ }^{5}$ son inteligentemente utilizados en su

\footnotetext{
${ }^{2}$ Véase su artículo "Evolución sintáctica y forma interior del lenguaje", en Actas del XI Congreso Internacional de Lingüística y Filología Románicas, 1865, Madrid, C.S.I.C., 1968 págs. 131-150.

${ }^{3}$ Lapesa, Rafael, Asturiano y provenzal en el Fuero de Avilés, Acta Salmanticensia, II, Salamanca, 1948. Próximamente será publicada la rica documentación que acompañaba al estudio lingüístico y que se había omitido hasta ahora.

${ }^{4}$ Al estudio anteriormente citado hay que añadir sus trabajos "Los francos en la Asturias medieval y su influencia linguística”, Symposium sobre cultura asturiana en la Alta Edad Media, Oviedo, 1967, págs. 341-353; "Los provenzalismos del Fuero de Valfermoso de las Monjas (1189)”, Philological Quarterly, LI, 1972, págs. 54-59; "Rasgos franceses y occitanos en el lenguaje del Fuero de Villavaruz de Rioseco", Mélanges Paul Imbs, Travaux de Linguistique et de Littérature, XI, Strasboyurg, págs. 529-532, y "El dialecto asturiano-occidental en los documentos notariales de la baja Edad Media”, en Homenaje a Vicente García de Diego, Revista de Dialectología y Tradiciones Populares, XXXII, 1976̆, págs. 225-245.

${ }^{5}$ Véase Diego Catalán, "En torno a la estructura silábica del español de ayer y del español de mañana, en Sprache und Geschiche, Festschrift für Harri Meier zum 65 Geburtstag, München, 1971, págs. 77-110. También Moreno Bernal, Jesús, Estudio lingüístico del ms. escurialense 1-1-6, Biblia romanceada de la primera mitad del siglo XIII, Universidad Complutense de Madrid, 1975; posteriormente "Les conditions de l'apocope dans les anciens textes castillans", en Le passsage à l'ecrit des langues romanes, Scriptoralia, 46, Gunter Narr, Tübingen, págs. 192-206.
} 
explicación como factores concurrentes con la fuerte influencia francesa que tanto influyó en Castilla entre 1080 y 1270.

Todo esto no quiere decir que Lapesa permaneciera ajeno a las corrientes estructuralistas que sustituyeron el historicismo lingüístico de sus maestros. Él mismo nos recordaba a sus discípulos que en sus jóvenes años de Salamanca ya introdujo en sus cursos el estudio de la fonología. Ocurre, sin embargo, que tenía la firme convicción de que las descripciones sistemáticas de validez general, sobre las que se basa el método estructural, deberían ir precedidas de una documentación exhaustiva que sirviera de sólido basamento a cualquier modelo explicativo y que, en cualquier caso, ninguno de ellos podía entrar en contradicción con la realidad lingüística ${ }^{6}$, hecho éste que, a veces, no se ha tenido suficientemente en cuenta en algunos trabajos de corte estructuralista. A lo que sí ha permanecido ajeno ha sido a los intentos, con dudosos resultados hasta ahora, de la lingüística generativa por ofrecer explicaciones históricas.

Cuando Lapesa inició su proyecto de elaboración de una Historia de la lengua de carácter general, contaba sólo con los trabajos de la escuela de Menéndez Pidal. El mismo maestro proyectaba una Historia de la lengua española, que quedó inconclusa y que aparecerá en breve, editada por Diego Catalán ${ }^{7}$. Sin embargo, la preocupación por conocer el origen de la lengua española y los procesos que la habían de convertir en lengua universal era ya patente desde el siglo XVI. A fin de valorar debidamente la obra de Lapesa, haré un breve recorrido por las principales aportaciones existentes en la historiografía lingüística española.

\section{LA HISTORIA DE LA LENGUA ESPAÑOLA EN EL SIGLO DE ORO.}

El primero que se interesó por esta cuestión fue Nebrija, pero lo hizo no como historiador de la lengua castellana, sino en la medida en que se ocupó de la gramática y de la ortografía castellanas y su dependencia de las latinas. Nebrija, sin embargo, dejó bien establecido el origen latino de la lengua romance, introduciendo el concepto de corrupción lingüística. Aunque no habla de latín vulgar, en su esbozo de explicación del proceso está implícito tal concepto, por más que una de las causas de tal corrupción se atribuyera a la influencia de los godos. A Nebrija le interesó más la comparación entre el latín clásico, tal como él propugnaba, que el estudio de los procesos históricos de evolución. Ni siquiera puede aducirse que viera en la obra de los escritores latinizantes del siglo XV el modelo del romance de su época. Es verdad que en Nebrija existió una idea de perfeccionamiento del romance, lo que implica un cierto sentido de evolución histórica, pero en realidad se refiere a la lengua artística, no a la lengua común, que estima culminada. Quizás esto explique su

\footnotetext{
${ }^{6}$ Véase su artículo "Sobre problemas y métodos de una sintaxis histórica", en Homenaje a Xavier Zubiri, II, Madrid, Sociedad de Estudios y Publicaciones, 1970, págs. 199-213.

${ }^{7}$ Así aparece en los proyectos de próxima publicación anunciados por la Fundación Menéndez Pidal. Noticias de esta Historia de la lenguá en D. Catalán, Linguíística ibero-románica, Madrid, Gredos, 1974, págs. 125-127.
} 
erróneo juicio acerca de que el romance hubiera llegado a tan alto estado "que más es de temer su deçendimiento que su perfección" ${ }^{\prime 8}$.

Las escasas referencias de Nebrija a la evolución del romance se hallan dispersas en toda su obra. Alguna mayor importancia poseen su Ortografía y su Vocabulario. En la primera porque adopta como referencia los valores fonológicos de la pronunciación pero tiene la ortografía latina como modelo, tal como le reprocharía un siglo más tarde Gonzalo Correas; el segundo porque proporciona una información etimológica fiable, que es la base de cualquier estudio de tipo histórico.

Aún siendo un ensayo sobre el uso lingüístico, el Diálogo de la lengua de Juan Valdés ${ }^{9}$ contiene algunas ideas interesantes sobre la evolución de la lengua. Por lo pronto, advierte que lo que habían hecho las supuestas "autoridades" del siglo XV era más "escrivir mal latín que buen romance". Carece Valdés de ideas claras acerca del origen de la lengua castellana; de ahí proceden sus vacilaciones: aún reconociendo que la mayor parte de los elementos lingüísticos del romance proceden del latín, se inclina a ver en el griego, desechando, eso sí, el vasco, el origen de la primitiva lengua hablada en España. Al griego, sustituido después por el latín, le cabe la gloria de haber constituido el sustrato prerromano más importante de España. Que esta idea estuviera o no determinada por el deseo de encontrar para nuestra lengua el antecedente más glorioso no oculta el error histórico y filológico en que incurre. Lo que no hay en Valdés es dato alguno de naturaleza filológica; todos los testimonios aducidos son históricos y, además, manejados con evidente abuso al valorar las noticias de los historiadores antiguos. En cambio, sí acepta la teoría de la corrupción lingüística para explicar el nacimiento del romance.

\section{LA POLÉMICA SOBRE EL ORIGEN DE LA LENGUA CASTELLANA.}

En las polémicas sobre el origen de la lengua española, el asunto que suscitó mayor interés giró en torno a la disparatada teoría de López Madera ${ }^{10}$, de la que se hicieron eco humanistas de segunda fila como Andrés de Poza $^{11}$ en 1587, Luis de las Cuevas ${ }^{12}$ y, lo que es más sorprendente, un humanista y filólogo de primera categoría como fue Gonzalo Correas $^{13}$, empeñados todos ellos en hacer creer que la primitiva lengua española era

\footnotetext{
${ }^{8}$ Tal como sostiene Eugenio de Bustos, esto no supone que considerara como modelo de lengua la de los escritores latinizantes del siglo XV. Véase Bustos Tovar, Eugenio de, "Nebrija, primer lingüista español”, en el volumen Nebrija y la introducción del Renacimiento en España, Actas de la III Academia Renacentista, Salamanca, 1983, págs. 205-222.

${ }^{9}$ Véase el prólogo de Rafael Lapesa al Diálogo de la lengua en Clásicos Ebro, Zaragoza, $2^{\mathrm{a}}$ ed., 1946.

${ }^{10}$ López Madera, Gregorio, Excelencias de la monarquía y reyno de España, Madrid, 1625.

${ }^{11}$ Poza, Andrés de, Antigua Lengua de las Españas, ed. de A. Rodríguez Herrero, Biblioteca Vasca, IV, Madrid, 1959.

${ }^{12}$ Cuevas, Luis de las, Diálogo de las cosas notables de Granada y lengua española, Sevilla, 1603.

${ }^{13}$ Correas, Gonzalo, Arte grande la lengua española castellana, ed. de Emilio Alarcos García, Madrid, C.S.I.C., 1950 .
} 
hablada en la Península Ibérica antes de la llegada de los romanos, según probaba un pergamino escrito en puro castellano supuestamente mil quinientos años de la llegada de los romanos. Esta tesis, defendida con ardoroso vigor, sólo es explicable como consecuencia de un nacionalismo imperial, llevado hasta el paroxismo, que otorgaba al español las más nobles cualidades, superiores a las de cualquier lengua clásica.

En sentido estricto, la primera obra que puede considerarse ya una historia de la lengua española es la de Bernardo de Aldrete $^{14}$, quien rebate de manera contundente a Madera y sus seguidores, aunque recurriendo a la argucia de atribuir valor profético al mentado pergamino encontrado en el Monte Santo de Granada, pero afirma de manera clara la común pertenencia de las lenguas románicas al tronco latino. Establecido el origen latino, admite la influencia de otras lenguas, como sustratos prerromanos, helenismos, germanismos y arabismos, en forma de préstamos léxicos. Acertada es asimismo, en términos generales la descripción de la expansión del castellano primitivo por la Península Ibérica. Con todo, la mayor novedad de la obra de Aldrete reside en la percepción de una evolución interna de la lengua. No se trata en sentido estricto de una fonética histórica ${ }^{15}$, aunque Aldrete considera que la "corrupción" no es sólo consecuencia de la influencia de otras lenguas, sino también de un proceso inherente a su naturaleza histórica, tal como se afirma explícitamente: "Digo lo primero, que la lengua con el tiempo se muda, i poco a poco siendo otra, de manera que sin nueuo acidente, más que el que el tiempo causa basta para que una lengua sea casi otra de la que fue agora trezientos años..."

La teoría de la corrupción del latín como origen del castellano fue seguida por la mayoría de los humanistas españoles, salvo el caso citado de Gonzalo Correas ${ }^{16}$. Además, el importante papel que el léxico desempeña en la obra de Aldrete tuvo su correlato en la más importante obra de la filología española del Siglo de Oro, que fue el Tesoro de Covarrubias $^{17}$. Aunque, como es bien sabido, se trata de una obra de naturaleza lexicográfica, el Tesoro contiene noticias históricas de capital importancia para la semántica histórica y es, desde luego, el antecedente más importante del Diccionario de Autoridades que redactarían los primeros académicos en el siglo XVIII.

\footnotetext{
${ }^{14}$ Aldrete, Bernardo José de, Del origen y principio de la lengua castellana o romance que oi se usa en España, ed. facsimilar y estudio de Lidio Nieto Jiménez, Clásicos Hispánicos, Madrid, C.S.I.C., 1975.

${ }^{15}$ Lidio Nieto ha reconstruido un esquema de fonética histórica con las ideas expuestas por Aldrete, que muestra la modernidad de sus ideas.

${ }^{16}$ Véanse las obras de Ambrosio de Morales, Discurso sobre la lengua castellana, de 1546; Alejo Venegas, Breve sentencia de las sentencias y vocablos obscuros que en el Libro del Tránsito de la Muerte se hallan, Toledo, 1543; Martín de Viciana, Libro de las alabanças de las lenguas hebrea, griega, latina, castellana y valenciana, de 1574; Antonio del Corro, Reglas gramaticales para aprender la lengua española y francesa, Oxford, 1586; Fray Jacinto de Ledesma, Dos libros de la lengua primera de España, de 1626; Francisco Cascales, Cartas philologicas, de 1643, Ximénez Patón, B. Epítome de la ortografía latina y castellana, ed. de A. Quilis y J.M. Rozas, Madrid, C.S.I.C., 1965. De las primeras véanse las referencias en Biblioteca Histórica de la Filología Castellana, del Conde de la Viñaza, Madrid, Manuel Tello,1893.

${ }^{17}$ Covarrubias, Sebastián de, Tesoro de la Lengua Castellana o Española (1611-1647), ed. de Martín de Riquer, Barcelona, Horta, 1953; nueva edición Madrid, Turner, 1972, 1976.
} 


\section{LOS ESTUDIOS HISTÓRICOS TRAS LA CREACIÓN DE LA REAL ACADEMIA ESPAÑOLA.}

Durante el siglo XVIII, interesa ante todo el aspecto normativo del uso lingüístico. Frente al abuso, ya degradado, del culteranismo barroco y también en lucha con el neologismo innecesario de origen francés, surgen una serie de obras en las que sólo de modo incidental se alude a la historia de la lengua española. Berganza ${ }^{18}$, Feijoo ${ }^{19}$, Sarmiento ${ }^{20}$ Capmany $^{21}$, Forner ${ }^{22}$, Fernández de Navarrete ${ }^{23}$, Vargas Ponce ${ }^{24}$, etc. plantean la cuestión lingüística desde una perspectiva apologética. Distinto es el caso de Mayans y Siscar ${ }^{25}$, quien, además de sus ideas sobre el origen innato del lenguaje, basado en la "infusión divina", tiene un claro sentido de la evolución lingüística; de este modo, compara las lenguas con ríos que, denominándose de la misma manera en todo su curso, lleva siempre aguas diferentes ${ }^{26}$. Interesantes perspectivas ofrece la obra de Mayans; desde su negativa a aceptar las estrafalarias ideas sobre el origen prerromano del español hasta sus importantes aportaciones en el campo de la etimología y de la ortografía. Menos acertado está en su peculiar forma de concebir el cambio fonético, pero ello no quita mérito al intento de dar explicación racional a este aspecto del cambio lingüístico. Mayans carecía de una idea "científica" de la evolución lingüística. En todo caso, es el primer lingüista que trata de dar una explicación coherente del origen y evolución de la lengua española, por más que no poseyera las herramientas precisas para lograrlo. Haría falta cerca de un siglo para que triunfaran los criterios historicistas de los neogramáticos, que son la base del desarrollo de la filología moderna.

\footnotetext{
${ }^{18}$ Berganza, Francisco de, Antigüedades de España propugnadas en las noticias de sus Reyes y Condes de Castilla la Vieja, 1713.

${ }^{19}$ Feijoo, Fray Benito Jerónimo, "Paralelo de las lenguas castellana y francesa", Discurso XV del Teatro crítico universal, Madrid, 1780.

${ }^{20}$ Sarmiento, Fray Domingo, Elementos etimológicos según el método de Euclides..., en Biblioteca histórica de la Filología castellana del Conde la Viñaza, Madrid, Manuel Tello, 1893.

${ }^{21}$ Capmany, Antonio de, "Del origen y formación de la lengua castellana", tomo I, págs. CXXIII-CCXXIII de su Teatro histórico crítico de la eloqüencia española, Madrid, 1786,

${ }^{22}$ Forner, Juan Pablo Exequias de la lengua castellana, ed. de P. Sáinz Rodríguez, Madrid, Clásicos Castellanos, Espasa-Calpe, 1925.,

${ }^{23}$ Fernández de Navarrete, M., "Sobre la formación y progresos del idioma castellano", en Memorias de la Real Academia Española, III, 1871, págs. 230-241. Madrid, 1972.

${ }^{24}$ Vargas Ponce, José de, Declamación contra los abusos introducidos en castellano, seguido de una Disertación acerca de la lengua castellana, Madrid, Impr. Viuda de Ibarra, 1795.
}

${ }^{25}$ Mayans y Siscar, Gregorio, Orígenès de la lengua española, Madrid, 1737.

${ }^{26}$ Sobre las ideas lingüísticas de Mayans véase el discurso de doctorado honoris causa pronunciado por Rafael Lapesa en la Universidad de Valencia, 1985, publicado en el volumen Estudios lingüísticos, literarios y estilísticos, Valencia, 1987, págs. XIII-XX. Reimpreso en el volumen El español moderno y contemporáneo, Barcelona, Crítica, 1996, págs. 55-66. Con posterioridad han aparecido algunos estudios notables sobre la obra de Mayans; destacaré entre ellos el de María José Martínez Alcalde, Las ideas lingüísticas de Gregorio Mayans, Ayuntamiento de Oliva, 1992 
El siglo XIX conoce un torrente de opúsculos en los que de manera directa o indirecta, casi siempre en forma de elogios, se incide en la historia de la lengua. Muchos de ellos son discursos académicos. Citaré, entre otros, los de Martínez Marina ${ }^{27}$, Ramírez y las Casas Deza $^{28}$, Gil y Zárate ${ }^{29}$, Pidal $^{30}$, Monlau $^{31}$, Valera $^{32}$, Pascual $^{33}$, Madrazo $^{34}, \mathrm{Mir}^{35}$, Commelerán ${ }^{36}$, Lasala ${ }^{37}$ etc. Son todos ellos discurso de recepción o de contestación leídos en la Real Academia Española y, en general, apenas aportan nuevas ideas sobre la historia de la lengua.

Más alcance poseen las primeras obras monográficas, ya con carácter científico, dedicadas a esclarecer asuntos concretos de la historia de la lengua española cuando no a tratar de esbozar el marco general de su historia. Aparte de obras en las que todavía no hallamos incorporados los nuevos métodos de la lingüística positivista, como la de Ximénez de Embún ${ }^{38}$, y de otras de carácter comparatista como la de Farré y Carrio ${ }^{39}$, la primera obra que es preciso mencionar es el opúsculo de Andrés Bello "Apuntes sobre el

\footnotetext{
${ }^{27}$ Martínez Marina, M., "Ensayo histórico crítico sobre el origen y proceso de las lenguas, señaladamente del castellano", en Memorias de la Real Academia de la Historia, tomo IV, Imprenta Sancha, 1805.

${ }^{28}$ Ramírez y las Casas Deza, Luis María, "Memoria sobre el origen de la lengua castellana”, en Memorias literarias de la Real Academia de Buenas Letras de Sevilla, tomo II, Sevilla, 1843.

${ }^{29}$ Gil y Zárate, Antonio, "Algunas causas que han debido contribuir a desnaturalizar la índole primitiva de la lengua castellana”, en Discursos de la Real Academia Española, I, págs. 541-559.

${ }^{30}$ Pidal, Pedro José, "Formación del lenguaje vulgar en los códices españoles", en Discursos de la Real Academia española, incluido en Estudios literarios, tomo I, Madrid, Manuel Tello, 1890.

${ }^{31}$ Monlau, Pedro Felipe, "Del origen y formación del romance castellano", en Discursos de la Real Academia Española, tomo II, Madrid, 1861. Del mismo autor, "Del arcaísmo y el neologismo. ¿Cuándo se debe considerar fijada una lengua?", en Memorias de la Real Academia Española, I, 1863, 123 páginas. Notable para la época es asimismo su Diccionario etimológico de la lengua castellana (ensayo) precedido de unos Rudimentos de etimología, Madrid, M. Rivadeneyra, 1856, 554 páginas.

${ }^{32}$ Valera, Juan, "Idea vulgar que hoy se tiene del habla castellana y sobre la idea que, en mi sentir, debe tener la Academia", en Memorias de la Real Academia, 1862.

${ }^{33}$ Pascual, Augusto, "De las lenguas románicas y de su influencia en la formación de la española", en Memorias de la Academia Española, tomo V, 1876.

${ }^{34}$ Madrazo, P., "El estado de la lengua castellana en el siglo de oro", en Discursos de la Real Academia Española, Madrid, 1881.

${ }^{35}$ Mir, Miguel, "Causas de la grandeza y perfección de la lengua castellana en el Siglo de Oro de nuestra literatura”, en Memorias de la Academia Española, VIII, 1902, págs. 493-569.

${ }^{36}$ Commelerán, Francisco A., "Leyes que regulan las transformaciones que sufre la palabra latina para convertirse en castellana”, en Discursos de la Real Academia española, Madrid, 1890.

${ }^{37}$ Lasala, Manuel, Del más antiguo uso del romance español entre los pueblos de nuestra Península, Folletín de "El Aragón", Zaragoza, Gregorio Juste, 1863, 89 páginas.

${ }^{38}$ Ximénez de Embún y Val, Tomás, Lengua española en el siglo de oro y su literatura: cambios notables que ha sufrido, diferencias principales que la distinguen de como ahora comúnmente se usa, Zaragoza, 1897.

${ }^{39}$ Farré y Carrio, Ignacio, Gramática histórica de las lenguas castellana y catalana, Barcelona, 1884.
} 
estado de la lengua castellana en el siglo XIII"40, con acertadas observaciones sobre la evolución de la lengua en ese período. También Amador de los Ríos ${ }^{41}$ se hace eco de los nuevos vientos de origen germánico que estaban modernizando profundamente los estudios históricos. Con todo, la que puede ser considerada la primera obra de la romanística española es la de Milá y Fontanals ${ }^{42}$, quien, aunque carente de la formación positivista que triunfaba en Alemania, encara con visión historicista el origen común de las lenguas románicas y la relación existente entre ellas, con especial atención al estudio del provenzal y del catalán en la Edad Media ${ }^{43}$. Al final de siglo, la filología española se incorpora plenamente a las nuevas corrientes, en las que se aprecia la fuerte influencia de los grandes maestros de la romanística como $\operatorname{Diez}^{44}$ y Meyer-Lübke ${ }^{45}$. Las Disquisiciones de filología castellana, de Rufino José Cuervo ${ }^{46}$ son de 1895 y en seguida aparece la figura de Menéndez Pidal, con su primer estudio sobre la leyenda de los infantes de Lara, publicado ya en 1896. Pocos años más tarde, 1904, apareció la primera edición de su Manual elemental de gramática histórica española, que ha estado vigente durante decenios. De 1906 son sus trabajos fundamentales sobre El dialecto leonés y la edición de la Primera Crónica General. Es, pues, en la transición entre los siglos XIX y XX, coincidiendo con la crisis del 98, generación a la que perteneció Menéndez Pidal, cuando se inaugura lo que había de ser la gran escuela de filología española, en la que había de formarse años más tarde Rafael Lapesa ${ }^{47}$.

\footnotetext{
${ }^{40}$ Bello, Aridrés, "Apuntes sobre el estado de la lengua castellana en el siglo XIII", en Obras completas, Santiago de Chile, 1801, págs. 305-329.

${ }^{41}$ Amador de los Ríos, José, "Sobre los orígenes y formación de las lenguas romances. Lengua castellana", en Historia crítica de la literatura española, 7 vols., Madrid, 1861-65, vol. II, págs. 361-414.

${ }^{42}$ Milá y Fontanals, Manuel, Estudios sobre los orígenes y formación de las lenguas romances y especialmente de la provenzal, en Obras completas coleccionadas por Menéndez Pelayo, 5 volúmenes, Barcelona, Librería de Álvaro Verdaguer, 1888-1895. Para el castellano, véase tomo IV, págs. 75-125.

${ }^{43}$ Por otra parte, Dámaso Alonso ha señalado la relación que existió entre Milá y Menéndez Pidal; véase Alonso, Dámaso, "Pluralidad y unidad temáticas en la obra de Menéndez Pidal”, en ¡Alça la voz, pregonero!, Homenaje a don Ramón Menéndez Pidal, Madrid, 1979, págs.17-42.esp. p. 18. Lo que más interesó a Menéndez Pidal de Milá fue su intento por reconstruir la poesía heroico-popular, al que responde el libro de éste De la poesía heroico-popular castellana. Estudio precedido de una oración acerca de la literatura española [1874], Barcelona C.S.I.C., 1959. A ese interés corresponde el primer trabajo pidalino sobre la leyenda de los infantes de Lara.

${ }^{44}$ Diez, Friedrich, Grammatik der romanischen Sprachen, $1^{\text {a }}$ edición Bonn 1836-44, $3^{\text {a }}$ edición 1870-1872. Para el castellano interesa el volumen III de là tercera edición, preferiblemente de la traducción francesa.

${ }^{45}$ Meyer-Lübke, W., Grammatik der Romanischen Sprachen, 4 vols. Traducción francesa Grammaire des langues romanes, París, 1890, 3 vols.

${ }^{46}$ Cuervo, Rufino José, Disquisiciones de filología castellana, en Obras completas, Instituto Caro y Cuervo, 1954.

${ }^{47}$ Véase Lapesa, Rafael, "Menéndez Pidal, creador de escuela: el Centro de Estudios Históricos", en el volumen ¡Alça la voz pregonero! Homenaje a don Ramón Menéndez Pidal, Madrid, 1979, págs. 43-79.
} 


\section{RAFAEL LAPESA EN LA ESCUELA DE MENÉNDEZ PIDAL}

No es ésta la ocasión adecuada para describir con precisión el lugar que Lapesa ocupa en la escuela de Menéndez Pidal ${ }^{48}$. Señalaré para lo que ahora interesa que su primer maestro fue Américo Castro ${ }^{49}$. De su mano ingresó en el Centro de Estudios Históricos, donde Menéndez Pidal ejercía un magisterio absoluto, y al círculo de sus intereses científicos había de permanecer siempre fiel. Lapesa ha descrito el método de trabajo de Menéndez Pidal y las extraordinarias consecuencias que tuvo para la filología española ${ }^{50}$. Fruto de esa fidelidad han sido las líneas maestras que rigen toda la obra de Rafael Lapesa y, de modo particular, su concepción de la historia de la lengua. En realidad, don Ramón dirigió desde el principio su investigación filológica: desde los estudios sobre el Fuero de Avilés y la presencia de elementos provenzales en los textos jurídicos primitivos, ya citados más arriba ${ }^{51}$ hasta sus primeros trabajos de interpretación lingüística de textos literarios ${ }^{52}$, que constituyen elementos esenciales para una historia de la lengua. Del mismo modo, Lapesa se interesó por otros campos de estudio que también habían de formar parte de su concepción de la historia lingüística. Una parte sustantiva de ésta se halla integrada por la fonética histórica. A esta parcela ha dedicado Lapesa trabajos memorables. Sirvan como ejemplo de su pensamiento teórico y de su metodología, fundada en su idea de que los cambios lingüísticos son correlatos de cambios sociales y culturales, su explicación del proceso de pérdida de la vocal final ${ }^{53}$, sus estudios sobre la norma lingüística alfonsi ${ }^{54}$ o su interpretación sobre las confusiones de sibilantes a principios del siglo $\mathrm{XVI}^{55}$. No hace

48 Manuel Muñoz Cortés ha hecho una buena síntesis de los métodos de Lapesa y de su íntima relación con la escuela de Menéndez Pidal. Véase su artículo "Aspectos del texto histórico lingüístico (secundum Lapesam)", en Homenaje al profesor Lapesa, Universidad de Murcia, 1990, págs. 43-70.

${ }^{49}$ Véase Lapesa, Rafael, "Semblanza de Américo Castro", en Homenaje a Américo Castro (José Jesús de Bustos y Joseph Silverman, eds.), Madrid, Universidad Complutense, 1987, págs. 121-134. También "La huella de Américo Castro en los estudios de lingüística española", en el volumen Américo Castro: The Impact of His Thought Esssays to Mark the Centenary of His Birth, Madison, The Hispanic Seminary of Medieval Studies, 1988.

${ }^{50}$ Lapesa, Rafael, "Cómo enseñaba a trabajar don Ramón: sus obras y materiales inéditos”, Boletín de la Real Academia Española, LXVIII, 1988, págs. 398-402. Véase también "Don Ramón Menéndez Pidal. Ejemplo y doctrina", Filología, XIII (1968-69), págs. 1-32.

${ }^{51}$ Véase ut supra, n.3.

52 Podría servir de modelo su clarividente estudio sobre el lenguaje épico: "La lengua de la poesía épica en los cantares de gesta y en el Romancero”, en Anuario de Letras, México, IV, 1964, págs. 5-24, recogido en el volumen De la Edad Media a nuestros días, Madrid, Gredos, 1967, págs. 9-28.

${ }^{53}$ Lapesa, Rafael, "La apócope de la vocal en castellano medieval”, en Estudios dedicados a R. Menéndez Pidal, Madrid, 1951, págs. 185-226, y "De nuevo sobre la apócope de la vocal en castellano medieval", en NRFH, XXIV, 1975, págs. 13-23, en el que replica a las objeciones formuladas por Diego Catalán en el trabajo citado en n.4. Reimpresos ambos artículos en Estudios de historia lingüística española, Madrid, Paraninfo, Madrid, 1984, págs. 167-197 y 198-208 respectivamente.

54 Lapesa Rafael, "Contienda de normas lingüísticas en castellano medieval", en Actas del Coloquio hispano-alemán Menéndez Pidal, Tübingen, Max Niemayer, 1982, págs. 172-190. Reimpr. En Estudios de historia lingüistica española, cit., págs. 209-225.

${ }^{55}$ Lapesa, Rafael, "Sobre el ceceo y el seseo en España e Hispanoamérica", en Homenaje a Pedro Henríquez Ureña, Revista Iberoamericana, XXI, 1956, págs. 409-416, y "Sobre el ceceo y el seseo andaluces”, en Homenaje 
muchos años respondió contundentemente a ciertas críticas hechas a la interpretación pidalina del Cantar de Mio Cid, con un trabajo en el que queda patente cómo un método rigurosamente positivista se enlaza con una interpretación cultural y literaria ${ }^{56}$. El segundo elemento constitutivo de una historia de la lengua es el léxico. Sería imposible aquí señalar lo que Lapesa debe a la escuela de Menéndez Pidal en su formación como lexicógrafo. Largos años ha pasado trabajando sobre el vocabulario de los Orígenes del español, de los que acaba de aparecer el primer fascículo. Con ello, Lapesa enlaza una de sus primeras tareas en la escuela de don Ramón con el fruto de su madurez filológica. En medio, son innumerables los estudios etimológicos, así como el estudio del léxico que caracteriza a un autor o a una época. En este aspecto, debe señalarse la influencia de Dámaso Alonso, fino rastreador de antecedentes léxicos en la poesía gongorina y profundo conocedor de sus valores semánticos. Lapesa no le anduvo a la zaga. El estudio de la obra de Santillana ${ }^{57}$, siguiendo en cierta manera el modelo de María Rosa Lida en su estudio de la poesía de Juan de Mena, es uno de los trabajos de filología y de estilística más sólidos de nuestra historia lingüística. Lapesa coincide con Dámaso Alonso en otorgar un importante papel al léxico culto en la historia de la lengua y a ello ha dedicado estudios magistrales sobre la presencia del cultismo semántico primero en Garcilaso ${ }^{58}$ y, posteriormente, en Fray Luis de León ${ }^{59}$. Desde otro punto de vista, ha estudiado asimismo cómo el léxico, elemento esencial para la interpretación de la realidad, refleja el pensamiento de una época ${ }^{60}$. Este tipo de trabajos léxico-semánticos históricos ha dado como resultado varias tesis doctorales. La idea básica es la de que el vocabulario se agrupa en campos nocionales que reflejan la ideología y la cultura de un autor ${ }^{61}$, de un grupo generacional y cultural ${ }^{62}$, y de un período histórico ${ }^{63}$.

a André Martinet, I, Biblioteca Filológica, Universidad de la Laguna, 1957, págs. 67-94; reimpresos ambos en Estudios de lingüística histórica española, cit. págs. 249-284. De la fidelidad a sus maestros y amigos es ejemplo el cuidado y pulcritud con que publicó los dos primeros volúmenes del trabajo proyectado, y sólo parcialmente preparado, por Amado Alonso, De la pronunciación medieval a la moderna en español, ultimado y dispuesto para la imprenta por Rafael Lapesa, Madrid, Gredos, I, 1955, II, 1969.

${ }^{56}$ Lapesa, Rafael, "Sobre el Cantar de Mio Cid. Crítica de críticas. Cuestiones lingüísticas”, en Études de Philologie Romane et d'Histoire Littéraire offerts à Jules Horrent, Liège, 1980, págs. 213-231.

${ }^{57}$ Lapesa, Rafael, La obra literaria del Marqués de Santillana, Madrid, Ínsula, 1957.

${ }^{58}$ Lapesa, Rafael "El cultismo semántico en la poesía de Garcilaso", en Homenaje a Margot Arce, Revista de Estudios Hispánicos, Universidad de Puerto Rico, 1972, págs. 33-45.

${ }^{59}$ Lapesa, Rafael, "Latinismos semánticos en la poesía de Fray Luis de León”, en Homenaje a Antonio Tovar, Madrid, Gredos, 1972, págs. 243-251.

${ }^{60}$ Lapesa, Rafael, “Ideas y palabras: del vocabulario dela Ilustración al de los primeros liberales”, en Homenaje a Pedro Laín, Asclepio, XVIII-XIX (1966-67), págs. 189-218.

${ }^{61}$ Así lo refleja la tesis doctoral de Doris Ruiz Otín, Política y sociedad en el vocabulario de Larra, Madrid, Centro de Estudios Constitucionales, 1983.

${ }^{62}$ Véase Laín Martínez, Milagro, El vocabulario de la Institución Libre de Enseñanza, tesis doctoral, Madrid, Universidad Complutense, 1976.

${ }^{63}$ También es resultado de una tesis doctoral, dirigida por Lapesa, la importante obra de Pedro Álvarez de Miranda Palabras e ideas: el léxico de la Ilustración temprana en España, Anejos del Boletín de la Real Academia Española, Madrid, 1992. 
Desde otro punto de vista, Lapesa ha contribuido tanto a los estudios etimológicos ${ }^{64}$ como a los lexicográficos ${ }^{65}$ y los ha insertado en su visión global de la historia de la lengua española.

Atendiendo la antigua sugerencia de su maestro Américo Castro, Lapesa se aplicó desde los años sesenta a los estudios de sintaxis histórica del español. Iniciaba así un camino que habría de dar frutos granados en los decenios siguientes. En otro lugar de este volumen se da cumplida cuenta de lo que el esfuerzo de Lapesa ha significado en la filología española. Baste aquí con indicar la importancia que estos trabajos han tenido en la renovación de su historia de la lengua española. No sólo han aclarado cuestiones lingüísticas esenciales de la gramática española en un campo en el que apenas había incidido Menéndez Pidal, sino que han cambiado aspectos importantes de la interpretación de los textos y del valor lingüístico (cronológico, estilístico, etc.) que se han incorporado a la descripción general de la historia lingüística.

\section{EL PROYECTO DE UNA HISTORIA DE LA LENGUA ESPAÑOLA.}

Nada mejor que las palabras del propio Lapesa reflejan la intención que guió la redacción de su Historia de la Lengua Española, publicada por primera vez en 1942: "La presente obra ha sido escrita con el deseo de ofrecer una visión histórica de la constitución y desarrollo de la lengua española como reflejo de nuestra evolución cultural". Hay implícita en esta afirmación toda una declaración de la posición teórica de su redactor en la que junto, al núcleo fundamental de raíz pidalina, se unen ideas de origen neoidealista que tienen sus fuentes más lejanas en los dos estudios esenciales de $\mathrm{K}$. Vossler, El lenguaje como creación y evolución y Cultura y lengua de Francia $^{66}$, y el más próximo en el libro de Warburg, Évolution et structure de la langue française ${ }^{67}$. Ramón Menéndez Pidal declara en su prólogo que "la historia de la lengua española ha sido ya objeto de obras muy valiosas", pero la verdad es que no hallamos otras que las señaladas ya en este trabajo y las que el propio Lapesa cita de Entwistle ${ }^{68}$ y la notable, aunque escolar, de Oliver Asín ${ }^{69}$, a

\footnotetext{
${ }^{64} \mathrm{~A}$ fin de no detallar cada uno de ellos, véanse los recogidos en el volumen Léxico e historia.I Palabras (volumen preparado por Juan R. Lodares con la colaboración del autor), Madrid, Istmo, 1992.

${ }^{65}$ Véanse los artículos recogidos en el volumen Léxico e historia. II Diccionarios (volumen preparado por Juan R. Lodares con la colaboración del autor); Madrid, Istmo, 1992.

${ }^{66}$ Véanse Vossler, Karl, El lenguaje como creación y evolución [1905], Madrid, Poblet, 1929, y Cultura y lengua de Francia. Historia de la lengua literaria francesa desde los comienzos hasta el presente [1913], Buenos Aires, Losada, 1955.

${ }^{67}$ Wartburg, Walter von, Évolution et structure de la langue française [1934], traducción española de Carmen Chust, Evolución y estructura de la lengua francesa, Madrid, Gredos, 1966.

${ }^{68}$ Entwistle, W.J., The Spanish Language, Londres, 1936

${ }^{69}$ Oliver Asín, Jaime, Iniciación al estudio de la Historia de la lengua española, Zaragoza, 1938.
} 
salvo, claro está, de la que el propio don Ramón estaba preparando y quedó sin terminar, como se ha indicado más arriba ${ }^{70}$.

Existen, a mi juicio, dos etapas en el proceso de elaboración de la Historia de la lengua española de Rafael Lapesa. La reelaboración de la octava edición, en 1980, y en seguida la novena de 1981, con nuevas adiciones, marca el tránsito de una obra que, sin dejar de ser la misma, alcanza nuevas cimas de valor científico ${ }^{71}$. En efecto, Lapesa comenzó a escribir su Historia por incitación de Tomás Navarro Tomás, como se reconoce en la dedicatoria de la octava edición, en un contexto histórico, cultural y científico nada propicio. Disperso el grupo de investigadores que trabajaban en el Centro de Estudios Históricos y aislado don Ramón Menéndez Pidal, Lapesa, que había quedado durante la guerra civil como único "guardián" de aquel Centro, reanudó su trabajo tras la contienda con el firme propósito de recoger la herencia recibida y, en comunicación constante con sus antiguos maestros, casi todos ellos en universidades americanas, prosiguió el camino emprendido en los años precedentes. Lapesa se dio cuenta de que era necesaria una obra que, recogiendo los inmensos frutos logrados por la investigación pidalina, constituyera una descripción global de la evolución del español desde sus antecedentes prerromanos hasta la época actual. Para lograrlo, era necesario que confluyera un riguroso conocimiento de los datos lingüísticos con un sentido de la claridad expositiva que hiciera accesible el libro no ya a los especialistas, sino a ese estrato social que debía conocer, como un bien cultural, el significado de la historia lingüística. Lapesa, formado en una rigurosa disciplina científica, tenía además una clara vocación docente, tal como hemos podido comprobar -y beneficiarnos de ello- los muchos centenares de alumnos que hemos pasado por sus clases. Eso explica que la Historia sea ya desde la primera edición un modelo de rigor científico y también una fuente de aprendizaje de sólidos saberes lingüísticos. Sin didactismo alguno -ese mal que hoy tiende a trivializar por supuestas razones pedagógicas la formación cultural de los jóvenes que acceden al saber- la obra es un prodigio de claridad científica no exenta de amenidad para la lectura. Para él, enseñar consiste básicamente en difundir el saber con métodos científicos. Anticipándose a posiciones que hoy mantienen algunos, entre los que me encuentro, las ciencias humanas han de utilizar criterios científicos pero han de evitar un metalenguaje esotérico que lo haga inaccesible a los no iniciados. Esto es, lo contrario de algunas modas que han secado las fuentes del saber humanístico.

Lapesa no se limita a recoger lo aprendido de otros, sino que aporta luz en aquellos aspectos históricos que más penumbra arrojaban. Espléndida es su síntesis de la situación lingüística prerromana en la Península Ibérica y su explicación del papel que estas lenguas desempeñaron en la formación de los dialectos iberorrománicos, como lo es la interpretación del valor que tienen los primeros documentos escritos y literarios para describir el proceso de evolución. Todo el saber de Orígenes del español, de Menéndez

\footnotetext{
${ }^{70}$ Véase ut supra, n.7.

${ }^{71}$ El propio Lapesa ha descrito el proceso de elaboración de su Historia. Véase su artículo "Historia de una Historia de la Lengua Española, en Actas del I Congreso Internacional de Historia de la Lengua Española (Cáceres, 30 de marzo-4 de abril de 1987, II, Madrid, Arco-Libros, 1988, págs. 1771-1785.
} 
Pidal, aparece fundido con datos de otras procedencias para dar una exacta información acerca de la lengua en los tiempos oscuros. Además, ya en estos primeros capítulos aparece nítida la concepción lapesiana de la historia lingüística, basada, como se ha anticipado más arriba, en la correlación entre fenómenos lingüísticos y procesos sociales y culturales. Adviértase la sencillez con que relaciona la variación del cambio lingüístico con hechos de la vida cultural. al explicar la contienda entre soluciones distintas en la época primitiva: "el hecho de que en medio de la ignorancia ambiente, no desaparecieran las apetencias cultas, explica en buena parte las fluctuaciones del lenguaje durante este período"72. Guiado por esta idea, Lapesa no hace sólo historia externa sino que imbrica en la historia global tanto los fenómenos llamados externos como los que corresponden a la evolución interna de la lengua, proceso de fusión nada fácil, que aparece con una prodigiosa nitidez expositiva. Lapesa incorpora a su obra, además, el estudio de la lengua de los principales textos literarios de cada época, enlazando armónicamente con una de las direcciones de investigación que le han sido más queridas. Pero esto no obedece sólo a un gusto personal, sino a la convicción de que los textos literarios son, de entre los escritos, los que mejor reflejan, dejando a salvo su valoración estética y su naturaleza estilística, los procesos lingüísticos. No ignoro que esta idea está sometida a revisión actualmente. Algunos filólogos piensan que es preferible bucear en la lengua que se testimonia en los textos de archivo para descubrir la situación real de la evolución lingüística, con lo que los testimonios literarios perderían valor histórico-lingüístico. Al margen de que esto es descubrir un mediterráneo bien conocido y navegado por la escuela filológica española, resulta que los textos literarios proporcionan una dimensión del uso lingüístico que de ningún modo puede hallarse en otros textos escritos. Lapesa no hace una historia de la lengua literaria, sino que imbrica la lengua de los textos literarios en la historia de la lengua común. A mi juicio, una posición científica impecable ${ }^{73}$.

La Historia conoció diversas modificaciones y adiciones hasta la séptima edición de 1968. Ya desde años antes Lapesa deseaba someter la obra a una revisión profunda, intención siempre aplazada por su fecunda labor investigadora en la década de los sesenta y de los ochenta, en los que dio a conocer, entre otros muchos trabajos, sus principales artículos de sintaxis histórica. Un hecho anecdótico desencadenó por fin el proceso de revisión; un cambio editorial forzado por el comportamiento desleal de los que habían editado el libro hasta entonces facilitó la tarea. Comenzó así una nueva fase en la que la Historia se convierte en el monumento científico filológico que es actualmente. Lapesa había progresado en las diversas direcciones de investigación que había cultivado; dueño de una prodigiosa capacidad de análisis de los datos, estaba en condiciones de hacer la gran labor de síntesis. Y esto es lo que hizo entre 1975 y 1980. De este modo, a los dos años de su jubilación administrativa, apareció la octava edición "refundida y muy aumentada" de su Historia de la Lengua Española.

\footnotetext{
${ }^{72}$ Lapesa, Rafael, Historia de la Lengua Española, Madrid, Escelicer, 1942. Cito por la 5a ed., de 1959, p.113.

${ }^{73}$ El estudio lingüístico de textos medievales ha sido impulsado por Menéndez Pidal entre sus discípulos. Recuérdense, entre otros, los trabajos de Manuel Ariza en este sentido. A ellos se añaden'multitud de tesinas y tesis doctorales sobre textos fundamentales de la Edad Media, que sería imposible citar aquí.
} 
Muchas son las novedades que ofrecía la nueva edición ${ }^{74}$. Toda la obra de Lapesa está presidida por el equilibrio y la ponderación. Admira su capacidad para revisar temas ya tratados en las ediciones anteriores, para incorporar nuevos testimonios procedentes de su investigación personal, para sintetizar en un todo coherente las aportaciones ajenas, para enfrentarse, en suma con los datos lingüísticos con la misma abierta curiosidad que en sus años juveniles. Lapesa revisa uno a uno todos los capítulos de su Historia. Redacta importantes adiciones al capítulo dedicado al estudio de las lenguas prerromanas y describe una panorama lingüístico de Hispania incorporando las últimas investigaciones realizadas en este campo. Muy revisada se halla asimismo la descripción de la romanización y de las características del latín hispánico. No soslaya temas como el de la cantidad vocálica y la diptongación que habían dado lugar a nuevas interpretaciones. Añade observaciones en torno al influjo del griego sobre el latín que quizás estén en el origen de ciertas construcciones romances del tipo va y dice, tomo y me voy, etc. ${ }^{75}$. La evolución del sistema casual latino y su progresiva sustitución por el régimen preposicional, la transformación del sistema deíctico latino, la aparición y desarrollo funcional del artículo como categoría gramatical y tantos otros temas de sintaxis históricas se benefician de su investigación personal.

Además de reelaborar epígrafes completos (como, por ejemplo, los referentes a "aspectos morfológicos y semánticos del arabismo" y "Arabismo semántico, fraseológico y paremiológico") Lapesa no elude enfrentarse a asuntos polémicos; así, toma posición respecto de la idea de que la introducción de arabismos alterase la preporción de voces oxítonas paroxítonas y proparoxítonas en el vocabulario español y esto favoreciese determinados tipos de palabras ${ }^{76}$. Se basa para ello en la calicata con la que ejemplifica el comportamiento acentual de arabismos y palabras españolas en relación con su estructura fonemática. Esa misma capacidad de precisión se advierte en las referencias que incluye en las notas. Sirva de ejemplo, la información sobre el uso de Hispania o Spania, que anuncia el tratamiento posterior de este asunto en el capítulo VIII ${ }^{77}$, donde tras citar los estudios de Américo Castro, José A. Maravall, Manuel Alvar, etc., establece sus propias conclusiones.

Lapesa sometió a profunda revisión la descripción del conjunto de cambios fonéticos que tuvo lugar en la época de orígenes. En este sentido, la nueva edición de la Historia incorpora elementos críticos sobre la naturaleza de estos cambios: la palatalización de $l-l$ y de $l$ - inicial, la diptongación, la suerte de la vocal final, etc. son aspectos de la evolución fonética integrados en una visión global del marco en el cual se produce el conjunto de cambios fonéticos. Lo mismo puede decirse de las precisiones añadidas al tema de la

\footnotetext{
${ }^{74}$ He resumido algunas de estas novedades en mi trabajo "El magisterio de Rafael Lapesa", en Cuadernos Hispanoamericanos, número 371, 1981, págs. 1-23. Recojo ahora algunos de los párrafos dedicados allí a este asunto.

${ }^{75}$ Véase Coseriu, Eugenio, "Tomo y me voy'. Un problema de sintaxis comparada europea”, en Vox Romanica, 25, 1, 1966, págs. 13-55. Reimpreso en Estudios de lingüística románica, Madrid, Gredos, 1977, págs. 79-151.

${ }^{76}$ Lapesa, R., Historia, cit., $8^{\text {a }}$ ed., págs. 147-148.

${ }^{77}$ Ibídem, págs. 201-202.
} 
primitiva dialectalización peninsular, sobre el dialecto navarro-aragonés, etc. Del cuidado con que Lapesa revisa el texto anterior es buen ejemplo el párrafo referente a la unidad lingüística española. Aunque es verdad que en los estudios de Menéndez Pidal se había puesto de manifiesto, de forma quizás exagerada, la consideración del romance castellano como variedad caracterizada por su disidencia respecto a las restantes lenguas iberorrománicas ${ }^{78}$, la Historia, sin rectificar al maestro, señala con precisión cómo se van consolidando las peculiaridades castellanas en relación con las de los dialectos románicos laterales.

El estudio lingüístico de los textos literarios se inserta, como se ha dicho más arriba, en el conjunto de la explicación histórica. Los criterios metodológicos de Lapesa, sólidamente enraizados en los de la escuela de Menéndez Pidal, se basan en la cuidadosa documentación de todos los hechos lingüísticos que son pertinentes para la explicación histórica. Por eso una de las preocupaciones de Lapesa fue contar con una colección de textos, literarios y no literarios, suficientemente representativos de cada época, para que sirvieran de fundamento a la historia de la lengua. Fruto de esa preocupación fueron los trabajos dirigidos por él mismo, con la colaboración de María Soledad de Andrés Castellanos, para acabar la Crestomatía del español medieval ${ }^{79}$, que constituye por sí sola una verdadera historia de la lengua. Con los datos procedentes del material utilizado para la Crestomatía, y con otros de diverso origen, Lapesa renueva aspectos esenciales de la Historia. Así, el estudio del español arcaico ofrece, junto a importantes modificaciones sobre la pronunciación antigua, valiosos juicios en torno a los textos literarios primitivos. Contaba, para ello, además, con numerosos trabajos sobre la lengua de las jarchyas, el lenguaje épico, Juan Ruiz, el lenguaje del amor cortés, las serranillas, etc. Una breve, pero importante, adición sobre el Cantar de Mio Cid matiza prudentemente la datación pidalina sobre la fecha de composición del Poema. Confirma, en cambio, su carácter de poesía oral, manifiesto en diversos recursos expresivos que constituyen peculiaridades del lenguaje épico. Los múltiples testimonios recogidos en su artículo, ya citado, "El Cantar de Mio Cid. Crítica de críticas. Aspectos lingüísticos" ofrecen una sólida base documental a las afirmaciones de Lapesa. Algunas de las notas características de ese lenguaje, como es el predominio de la yuxtaposición, valorada por Badía Margarit como manifestación de una "sintaxis suelta" frente a la denominada "sintaxis trabada", propia de los textos en prosa, incita a realizar una cuidadosa revisión del proceso de formación del sistema de conjunciones en las lenguas romances. El valor de la oralidad como elemento constitutivo y organizador del texto aparece sugerido

\footnotetext{
${ }^{78}$ Quizás sería mejor considerar el territorio peninsular como un "continuum" dialectal en el que paulatinamente van surgiendo peculiaridades que fueron configurando los distintos dominios lingüísticos; el castellano seria uno más de ellos. Véanse las rectificaciones a las ideas de Menéndez Pidal que formula Rafael Cano Aguilar en "Los orígenes del español: nuevos planteamientos", en Homenaje a Germán Colón, Madrid Gredos, 1998, págs. 127-140.

79 Crestomatía del español medieval, dirigida por Ramón Menéndez Pidal con la colabaración del Centro de Estudios Históricos. Acabada y revisada por Rafael Lapesa y María Soledad de Andrés Castellanos, Madrid, Seminario Menéndez Pidal-Editorial Gredos, t. I, 1965; t. II, 1966.
} 
con nitidez ${ }^{80}$. Una vez más, la nueva edición de la Historia se benefició de la tenaz y coherente línea metodológica seguida por su autor lo largo de toda su vida.

Ampliación importante afecta al tratamiento de los primeros textos en prosa, especialmente en lo que se refiere a los catecismos político-morales de la época de Fernando III, textos cuya importancia se ha puesto de manifiesto en las ediciones críticas que se han realizado en los dos últimos decenios. Estos textos ofrecen abundantes testimonios del esfuerzo que hubieron de realizar sus redactores por crear un léxico adecuado, flexibilizar la sintaxis y organizar un discurso que se resistía a la expresión de las ideas abstractas. Importantes observaciones formula el autor sobre La Fazienda de Ultramar y las primeras versiones bíblicas romanceadas. Apoyado en datos históricos y en alguna de las tesis doctorales dirigidas por él mismo ${ }^{81}$, describe la importancia que la literatura didáctica tuvo para el desarrollo del romance literario primitivo, como importante antecedente próximo de la prosa doctrinal e histórica alfonsíes. Abundantísimas son las adiciones al estudio de la obra de Alfonso X el Sabio. Lapesa hace numerosas precisiones: explica los aragonesismos y occitanismos en el Libro de las Cruzes, la procedencia de ciertos rasgos estilísticos y su relación con las fuentes textuales, etc. Se añaden noticias sobre la penetración del castellano en los documentos notariales del dominio navarroaragonés, redacta párrafos nuevos en torno a los textos postalfonsíes y describe el estado de lengua subsiguiente a la relativa estabilización lingüística de este período.

Múltiples son las adiciones que hace al estudio de la lengua de los textos literarios en la Edad Media. Advierte con perspicacia la penetración de la oralidad en la obra del mester de clerecía, recoge e integra la información proporcionada por las últimas ediciones del Libro de Buen Amor, llama la atención sobre la nueva veta poética que se manifiesta en el angustiado sentimiento religioso de don Pedro López de Ayala, cuyo intimismo lírico es novedad sorprendente en la literatura castellana. Todo ello fundido en la historia de la lengua común; su deseo de precisión se manifiesta en la meticulosidad con la que trata la alternancia del sufijo -illo / -iello. Dedica parágrafos totalmente nuevos a determinados aspectos de la lengua y de los textos literarios del siglo XIV, con epígrafes de nuevo cuño, como los titulados Cultismos y retórica y La literatura aljamiada. De este modo, advierte que, junto a la introducción de neologismos cultos, se producían frecuentes alteraciones en su estructura fonemática, con mutilaciones debidas a su uso oral. Estas deformaciones no eran exclusivas del latín vulgar, como había estudiado Américo Castro ${ }^{82}$; aparecen también en todos los textos literarios y son abundantes no sólo en la poesía goliardesca de Juan Ruiz, sino también en la prosa sabia de don Juan Manuel, en los Proverbios morales del

\footnotetext{
${ }^{80}$ Trabajos recientes han confirmado y enriquecido esta apreciación lapesiana. Véase el artículo de Francisco de Bustos, "Épica y crónica: contraste en la estructuración del discurso", en Actas del II Congreso Internacional de Historia de la Lengua Española, Madrid, Pabellón de España, 1992, págs. 557-568. También José Luis Girón, “Cohesión y oralidad. Épica y crónicas”, en Revisa de poética medieval, 1, 1997, págs. 145-170.

${ }^{81}$ Moreno Bernal, Jesús, Estudio lingüístico del ms. escurialense 1-1-6. Biblia romanceada de la primera mitad del siglo XIII, Madrid, Universidad Complutense, 1975.

${ }^{82}$ Castro, Américo, Glosarios latino-españoles de la Edad Media, Centro de Estudios Históricos, Madrid, 1936.
} 
Rabí don Sem Tob y en el Rimado de Palacio. Ello prueba la fácil asimilación de los cultismos en la lengua hablada, que se integran en el vocabulario común y son sometidos a los cambios fonéticos todavía vigentes hasta finales de la Edad Media. Será en la época del humanismo latinizante del siglo XV, continuado por el clasicismo del Renacimiento, cuando se quiebre esta tendencia. Lapesa nos impulsó a algunos de sus discípulos a estudiar esta evolución, lo que dio lugar a diversos trabajos ${ }^{83}$, también incorporados a su Historia.

Los estudios, con materiales siempre de primera mano, de Lapesa sobre los textos del siglo XV le permiten describir con notable coherencia los importantes cambios lingüísticos que comenzaron a gestarse en esta centuria y en las siguientes. Ofrece nuevos datos sobre el fenómeno de confusión de sibilantes en las hablas meridionales, describe la irrupción de la nueva corriente de latinización que inunda la literatura española y añade, en fin, agudas notas sobre la evolución estilística de escritores poco conocidos, como Juan de Lucena, que reflejan la dirección que iba tomando el latinismo prerrenacentista. Enseña así al lector el sentido que tenía la Antigüedad para los hombres del siglo XV y diseña, al mismo tiempo, el marco cultural en que se produce la evolución lingüística. Su preocupación por fundamentar todo juicio en los datos testimoniados en los textos es constante; por eso subordina la interpretación de los textos a la verificación de los datos filológicos, lo que le permite establecer cuál es el sentido que puede tener el concepto de prerrenacentista utilizado por María Rosa Lida para Juan de Mena, que ha sido puesto en duda en alguna ocasión. Particular interés tiene, por otra parte, su observación acerca de la importante influencia que tuvieron las traducciones en el proceso de creación lingüística durante este siglo y los inmediatamente posteriores. A estos datos ofrecidos por Lapesa habría que añadir algunos aspectos del lenguaje en las comedias humanísticas, difundidas en el ámbito escolar, que desempeñaron asimismo una importante función difusora de la escritura en la oralidad $^{84}$.

El estudio del español del Siglo de Oro ocupa dos capítulos. Innumerables son las rectificaciones y adiciones con que enriqueció su obra. Partiendo una vez más de sus propios trabajos y aceptando los más valiosos de los ajenos, Lapesa aborda los temas más importantes de este período de formación del español moderno; la descripción de los últimos cambios fonéticos del español medieval, el proceso de dialectalización subsiguiente, la lengua de los textos literarios, que adquiere ahora una considerable complejidad, la formulación de un ideal de lengua y la aparición de las polémicas lingüísticas que tuvieron lugar durante los dos siglos, la evolución sintáctica del español clásico, enriquecida con numeroso datos procedentes de su investigación sobre sintaxis

\footnotetext{
${ }^{83}$ Véanse mi Contribución al estudio del cultismo léxico medieval, Madrid, Anejos del BRAE, 1975, y "Notas sobre el cultismo léxico en la literatura medieval castellana", en Actas del XIV Congreso Internacional de Lingüística y Filología Románicas, Nápoles, 1974, págs. 233-250. En otro sentido, la magnífica tesis doctoral de Ramón Santiago, La primera versión castellana de "La Eneida" de Virgilio, Madrid, Anejos del Boletín de la Real Academia Española, 1979.

${ }^{84}$ Véase la tesis doctoral de Javier Herrero, La oración compuesta en la Comedia Thebaida, Madrid, Universidad Complutense, 1991. Para el plano léxico, mi artículo "Cultismo en el primer renacimiento", en Actas del Coloquio hispano alemán Menéndez Pidal Max Niemayer, Tübingen, 1982, págs. 15-39.
} 
histórica, etc. son otros tantos aspectos que quedan expuestos con sólida precisión en esta nueva edición de su Historia. Su intervención personal en la reelaboración y actualización de los materiales que le confió Amado Alonso dio lugar a la publicación de los dos primeros volúmenes y quedó pendiente el tercero, de más delicada redacción, porque corresponde a materiales que no había sido ordenados por su autor antes de su fallecimiento y que exigen, por tanto, una cuidadosa revisión, tanto más cuanto que Lapesa ha sido de una fidelidad extrema al encargo que le hizo Amado Alonso. La minuciosidad con que describe este complejo proceso de mutación fonética y fonológica y la exactitud de los datos que él mismo aporta ${ }^{85}$, revelan el motivo que ha llevado al autor a realizar este arduo trabajo de revisión de un manual, nacido con un propósito modesto y convertido en libro fundamental para conocer nuestra historia lingüística.

La teoría pidalina del "estado latente" halla nueva confirmación en el tratamiento que hace Lapesa de los fenómenos que dieron lugar a la aparición y desarrollo de las hablas meridionales. Igualmente clara es la descripción del proceso primitivo de expansión del español por América ${ }^{86}$ y de los factores de diversos origen y de naturaleza también diferente (indigenismos, afronegrismos, hablas criollas, origen de la emigración peninsular, asentamiento de la emigración, etc.) que han ido configurando las variedades del español en América.

\section{EL ESPAÑOL MODERNO Y CONTEMPORÁNEO.}

De la historia forman parte asimismo el pasado cercano y la configuración del presente. Casi doscientas páginas de su Historia dedica Lapesa a describir el estado del español moderno desde la codificación académica del siglo XVIII hasta nuestros días. Esto era posible porque a lo largo de toda su vida Lapesa no había dejado de interesarse por cuestiones relativas al español de hoy. Su intensa actividad en la Real Academia y su interés por las cuestiones léxicas y gramaticales dieron lugar a la publicación de numerosos artículos de naturaleza sincrónica. Por eso no puede sorprender a nadie la gran cantidad de información incorporada en las nuevas ediciones de su Historia, procedente en gran medida de su investigación personal. Tal ocurre en el estudio sobre los campos ideológicos del neologismo incorporado en la transición del siglo XVIII al XIX, la indagación sobre la aportación idiomática de Larra y de los poetas románticos, su enfoque sobre el problema que plantea la adopción de extranjerismos en el español actual, etc. Los tres capítulos finales, y de modo especial el último, dedicado al español de América, que casi duplica su extensión respecto de las ediciones anteriores, fueron completamente reelaborados. Como se ha anticipado más arriba, se estudian nuevos asuntos que, como el de la influencia del elemento africano y el de las hablas criollas, han sido objeto de importantes trabajos en los

\footnotetext{
${ }^{85}$ Véase, por ejemplo, el contenido de la pág. 372, n. 11 de su Historia.

${ }^{86}$ Complementando el trabajo de Menéndez Pidal "Sevilla frente a Madrid", Lapesa había estudiado la cuestión del andalucismo del español de América en su artículo “"'El andaluz y el español de América”, en el volumen Presente y futuro de la lengua española, Madrid, OFINES, II, págs. 173-82. La nueva edición de su Historia pone al día los datos sobre este asunto, lo que permite formular importantes precisiones.
} 
últimos años. La extensión del voseo, la descripción de los principales rasgos diversificadores del español en América, etc. Son otros tantos aspectos que han requerido la cuidadosa atención del autor y que quedan englobados en el marco de la historia de la lengua española.

La importancia que Lapesa concede a la evolución moderna y contemporánea del español se ha puesto de manifiesto más recientemente con la publicación de un volumen que recoge sus estudios en este marco cronológico: El español moderno y contemporáneo ${ }^{87}$. Las palabras de su autor en el prólogo revelan algo que siempre ha estado presente en el talante intelectual y científico de Rafael Lapesa: su pudorosa modestia. Creo que merece la pena recogerlas aquí: "Reúno en este volumen una serie de artículos publicados entre 1956 y 1993, obedientes a distintos estímulos y condicionados por diferentes circunstancias. Sin embargo, hay en ellos el afán común de presentar los fenómenos lingüísticos en relación estrecha con las transformaciones del vivir y pensar españoles a partir del siglo XVIII, con especial atención a los cambios ideológicos, políticos y sociales, y también a las innovaciones científicas, literarias y artísticas (la cursiva es mía). Al darlos ahora juntos a la imprenta no pretendo sino preparar de algún modo el camino para que otros mejores que yo (la cursiva es mía) continúen la historia de la lengua española que don Ramón Menéndez Pidal no llegó a terminar, y cuyo texto completo, que no alcanza sino hasta fines del siglo XVII, pronto verán la luz ${ }^{88}$ gracias a su nieto Diego Catalán...”. En efecto, las quinientas páginas de este volumen revelan varias ideas esenciales que han definido la figura intelectual de Rafael Lapesa. En primer lugar, el sólido sentido de la coherencia metodológica que ha dirigido toda su labor de investigación. Eso permite que exista una línea directriz que preside artículos publicados en 1956 con los elaborados casi cuarenta años después, dando continuidad a un sentido de la historia lingüística que entronca directamente con el pensamiento histórico de Menéndez Pidal, pero también con el de su otro maestro, don Américo Castro. A nadie se le escaparán las resonancias del concepto de "vividura" hispánica que existen también en las palabras prologales de Lapesa. Por eso, el sentido de continuidad de la indagación científica se justifica en la finalidad última que se le concede: se trata de un camino para interpretar la historia común de los españoles y del mundo hispánico que, entre todos, fue creándose partir de 1492. La segunda idea patente en esas palabras es su fidelidad al magisterio de Menéndez Pidal. Hasta tal punto llega su modestia que subordina sus trabajos -incluida su Historia- a la del maestro. Sin embargo, nada podrá cambiar la función formadora e informadora que los trabajos de lingüística histórica de Rafael Lapesa han cumplido a lo largo de varios decenios.

Dada la rigurosa coherencia interna que poseen todos los estudios de lingüística histórica de Lapesa, no puede sorprender que su volumen sobre el español moderno y contemporáneo constituya un precioso complemento de su Historia de la Lengua Española. En una primera parte recoge sus estudios sobre la lengua durante los siglos XVIII y XIX proyectados sobre dos asuntos básicos: 1) la relación entre palabras, ideas y cosas, cuestión

\footnotetext{
${ }^{87}$ Lapesa, Rafael, El español moderno y contemporáneo, Barcelona, Crítica (Grijalbo Mondadori), 1996.

${ }^{88}$ Cf. n. 7 de este trabajo.
} 
importante en la transición del mundo moderno al contemporáneo, y 2) las cuestiones de lengua y estilo en escritores fundamentales como Feijoo, Larra y Espronceda. Su estudio sobre el problema de la lengua en Feijoo es modélico. Se halla en la línea, mantenida invariablemente por Lapesa, de que los hechos de lengua reflejan los cambios culturales; de ahí deriva el valor que atribuye a la innovación estilística del escritor benedictino, nuestro "primer ilustrado" en palabras del propio autor, que creó una nueva fórmula en la que la escritura didáctica, el ensayo, adquiere las galanuras de un estilo cargado de expresividad. Ello justifica el parangón que Lapesa establece con Ortega y Gasset, aludiendo a la afirmación de éste de que "en España para persuadir es menester antes seducir".

La segunda parte del libro se refiere a cuestiones suscitadas en la época, de no escasa duración, en la que Lapesa dedicó una gran parte de su trabajo a la labor de la Real Academia $^{89}$. Cuestiones léxicas, gramaticales y de política lingüística ocupan una buena parte de estos estudios. En ellos se manifiesta como virtud básica la de la ponderación en el tratamiento de los asuntos lingüísticos, enfocados desde una visión universal. Jorge Guillén, en un poema magistral, definió a Lapesa como arquetipo de la discreción y de la mesura. Efectivamente, si alguna persona se ha ganado el derecho de poseer la virtud cervantina de la discreción ésta es Rafael Lapesa. Los estudios recogidos en este volumen lo manifiestan una y otra vez. A ese talante responde su concepción de la unidad del idioma, pensada como integración de sus variedades: "Cada hispanohablante culto debe hacer suya por el conocimiento y el amor toda creación verdadera nacida en nuestra lengua, donde quiera que haya surgido. Debe decir con Juan Ramón Jiménez: Un español no es el español ahora para mí; el español que yo quiero es todos los españoles. Y todos los hiapanoamericanos...Con este inteletto d'amore se provocarán influencias mutuas que conduzcan a la formación de una koiné. Es lo que se nos impone en tiempos de progresiva uniformidad en todos los órdenes de la vida. Esa koiné garantizaría por unos siglos más -quién sabe cuántos- la pervivencia de un español sin fracturas" ${ }^{\prime 90}$. Creo que estas palabras reflejan fielmente el modo en que Lapesa, en tantas cosas inspirador del pensamiento de la Real Academia durante estos años, ha superado el antiguo e inconveniente casticismo lingüístico que presidió los criterios normativos académicos desde su fundación hasta que Menéndez Pidal asumió su dirección.

Esta misma discreción lingüística se manifiesta en el conjunto de artículos referidos al español de América y a la debatida cuestión de la aceptación de neologismos. Su actitud abierta, aunque no alegremente permisiva, se manifiesta en muy diversos testimonios. Véamoslo con un ejemplo: "Sí, estamos inmersos en extranjerismo lingüístico.... Ocurre así en gran parte por frivolidad o ignorancia; en gran parte por cuquería propagandística: el marchamo foráneo deja boquiabiertos a los papanatas, y éstos abundan tanto que es práctico

\footnotetext{
${ }^{89}$ Largos años dedicó Lapesa al absorbente trabajo de la Real Academia. La deuda contraida con él es, en este sentido, inmensa. Muchos reconocimientos ha recibido por ello. Desgraciadamente, como es común entre humanos, no le han faltado los arañazos de la ingratitud cuando no de la envidia.

${ }^{90}$ Véase su artículo "América y la unidad de la lengua española”, en Revisa de Occidente, 2a época, IV, 1966. Reimpreso en El español moderno y contemporáneo. Estudios lingüísticos, cit. pág. 252.
} 
deslumbrarlos. Pero hay otra causa innegable y más profunda, y es que desde hace tres siglos vamos a remolque del restante mundo occidental, tanto en las innovaciones con que la ciencia y la técnica han cambiado las condiciones de la vida humana, cuanto en la exploración de nuevos derroteros para las ideas.... Con las ideas y las cosas vienen inevitablemente las palabras. Ante este hecho, las lamentaciones son tan inútiles como las protestas. La única actitud positiva consistirá en aprovecharnos del impulso ajeno tan hábilmente que en un futuro más o menos próximo podamos seguir nuestro camino con autonomía, y por lo que se refiere al lenguaje, asimilar lo necesario para que nuestro idioma se mantenga a la altura de los tiempos, sin dejar de responder a lo que éstos exigen; pero evitar en lo posible que tal puesta al día menoscabe su belleza y peculiaridad"91. Con este criterio respecto del neologismo, Lapesa enlaza con el pensamiento de un ilustrado, tan apreciado por el autor, como Feijoo acerca de este mismo asunto.

Su conciencia de historiador, el rigor de su método documental, la claridad de la descripción lingüística son constantes en la obra de Lapesa. Por eso mismo, no puede sorprender que el conocimiento de la historia de la lengua española suscite, a su vez, una honda preocupación por su uso actual y por su futuro. Repetidas veces ha alzado su voz contra el descuido, la ignorancia y la zafiedad con que utilizan nuestra lengua las gentes que tienen una fuerte influencia sobre la sociedad. Lapesa dedicó una buena parte de su esfuerzo a luchar por la educación lingüística de los españoles. En su primera juventud desde su oficio, siempre recordado, de catedrático de Instituto. Él mismo nos lo ha descrito con palabras llenas de ingenuidad" ${ }^{92}$ : "Mi estreno, descorazonador, fue con los niños de primer curso. Al abrir las puertas del aula, la invadió un centenar de críos en tropel, empujándose, apretujándose... Vi que se imponía como primeras metas conseguir que se expresaran con mayor claridad y corrección; despertar, mediante la lectura, la memoria visual y la precisión auditiva necesarias para desterrar cacofonías...; y lograr que practicaran en su experiencia oral y escrita una sintaxis y lógica aminorando anacolutos y faltas de concordancia..." Después, como profesor universitario, dedicó tanto tiempo a la enseñanza como al estudio y a la investigación. Siempre se confesó continuador de las ideas de Menéndez Pidal, aunque atento a las novedades que iban surgiendo. Aunque en 1992, lamentara no poder incorporar nuevas concepciones lingüísticas, Lapesa no ha dejado de estar dispuesto a aceptar cuantas ideas pudieran enriquecer el legado de Menéndez Pidal; eso sí, siempre que no supusieran la pérdida de la coherencia teórica y metodológica que ha inspirado todos sus trabajos. Por eso no evita pronunciarse acerca de ciertas ideas que estima perniciosas; la más grave le parece aquella que distorsiona la naturaleza histórica del lenguaje. Con el floreciente desarrollo de los estudios estructuralistas, surgidos inicialmente de una dicotomía que hoy se estima falsa, pareció que la lingüística histórica había llegado a un callejón sin salida. Lapesa no lo consideró nunca así; el tiempo habría de darle la

\footnotetext{
${ }^{91}$ Lapesa, Rafael, "'Kahlahtayood'. Madariaga ha puesto el dedo en la llaga”, en Revista de Occidente, $\mathrm{n}^{\circ} 36$ (marzo de 1966), págs. 373-380. Reimpreso en El español moderno y contemporáneo, cit., véase p. 414.

${ }^{92}$ Véase su artículo "Mi experiencia en la enseñanza del español y de la literatura", en Actas del I Congvreso Internacional sobre la enseñanza del español, Biblioteca Pedagógica, Madrid, 1992, págs. 13-22. Reimpreso en El español moderno y contemporáneo, cit., págs.483-492.
} 
razón. Lo que parecía una distinción irreductible era, en realidad, un nuevo enfoque que, desde el propio estructuralismo ${ }^{93}$, habría de incorporarse pronto a los métodos históricos: "La sincronía abstrae un momento de la diacronía y ésta no es sino una sucesión de sincronías. Por otra parte, ni la lingüística diacrónica, ni la historia literaria pueden desentenderse de la historia general. Los cambios lingüísticos y literarios incubados salen a la superficie cuando las circunstancias históricas los favorecen. Así ocurrió con la independización del castellano respecto del latín y con su extensión hegemónica; con el desarrollo de la apócope en el castellano arcaico como consecuencia de la inmigración franca en los siglos XI al XIII ...; con la formación del andaluz en las condiciones históricosociales de la Reconquista y la frontera con el Reino moro de Granada; con la transformación del sistema consonántico español y el triunfo del castellano norteño, instalado en la corte de Madrid, sobre el toledano..." "94. Muchos años después de haber iniciado su labor de historiador de la lengua, Rafael Lapesa manifiesta inequívocamente, una vez más, cuál ha sido el principio metodológico al que ha permanecido fiel. Seguramente fue esta concepción de que la historia de la lengua es una parte indisociable de la historia general la que impulsó a los académicos de la Real de la Historia a hacerlo uno de sus miembros. Su discurso de ingreso en la alta Institución sirvió para que el maestro se reafirmara en sus ideas.

Ya se ha dicho antes que la investigación lingüística fue para Lapesa el modo de manifestarse como intelectual de su época. Por eso no dejaron nunca de preocuparle los avatares de la sociedad civil en un tiempo tan difícil como el que le tocó vivir, aunque nunca aprovechó su condición de profesor para expresar ideas políticas. Sin embargo, desde su responsabilidad como intelectual y como filólogo simepre se interesó por cuanto lo rodeaba. Particular sensibilidad tuvo siempre por la actitud de los españoles ante su lengua y ante las demás lenguas de España. Esta preocupación se ha adensado en los últimos tiempos viendo cómo la cuestión lingüística se ha convertido en algunos lugares de España en arma arrojadiza, instrumento de política aldeana cuando no manipulación descarada al servicio de intereses espurios. Quizás sus ideas actuales estén llenas de excesivo pesimismo, pero faltaría a la objetividad si no lo reflejara en este artículo que pretende ser un homenaje a su papel de maestro de la historia lingüística española. Ya en su artículo "La responsabilidad de los intelectuales ante la lengua" ${ }^{25}$, de 1989 y, sobre todo, en el prólogo a su El español contemporáneo..., ya citado, escrito en 1994, manifestaba su honda preocupación: "Hubiera querido que mi aportación terminase con un 'canto de vida y de esperanza’. Así debería ser si nos limitáramos a pensar en el porvenir de nuestra lengua en América... pero esos motivos de exultante alegría tienen por contrapeso el descuido que en España padece su enseñanza; los defectos resultantes del apresuramiento o la improvisación

\footnotetext{
${ }^{93}$ Recuérdense los trabajos de Martinet, Coseriu, Alarcos Llorach y tantos otros que, desde planteamientos rigurosamente estructuralistas, han realizado aportaciones fundamentales para la historia de la lengua española.

${ }^{94}$ Lapesa, Rafael, "Mi experiencia en la enseñanza del español y de la literatura”, cit., véanse págs. 489-490. Véase también el prólogo, cit, .p. 8.

${ }^{95}$ Este texto corresponde a la conferencia pronunciada en 1989 en el Colegio Libre de Eméritos, publicada en su El español moderno y contemporáneo, cit., págs. 469-482
} 
con que forzosamente actúan periodistas y locutores; y, sobre todo, el espíritu de insolidaridad que está cundiendo en la parte española de la piel de toro y que, reabriendo heridas de pasados agravios -reales, por desgracia, en algunos casos, pero quiméricos en otros- convierte en rencorosas hermanastras a las lenguas hermanas de la nacional, o pretenden elevar a lenguas de cultura dialectos que nunca pasaron de ser conjuntos de variedades aldeanas". Quizás estas palabras sean, como he dicho, pesimistas en exceso, pero no dejan de revelar un aspecto de la realidad española actual, percibida angustiadamente por el maestro.

Rafael Lapesa escribió acerca de la historia de la lengua española y enseñó Historia de la Lengua. Difícil, por no decir imposible, es separar el Lapesa investigador del Lapesa profesor. En esto también es ejemplo. Cuando hoy algunos profesores universitarios se precian de "que no les gustar dar clases" porque se consideran sólo "investigadores" (distinción perfectamente admisible, pero que uno no acierta a comprender por qué tiene que expresarse en términos contradictorios), Lapesa se nos presenta como un modelo al que imitar. Él ha demostrado de manera patente que se pueden consagrar muchas horas de todos los días a la enseñanza; nunca olvidaremos aquellos exámenes que devolvía a sus alumnos cuidadosamente corregidos con observaciones llenas de agudeza, que eran por sí solas una fuente insustituible de aprendizaje. Inolvidables fueron sus consejos para que en la indagación etimológica los estudiantes "no inventáramos latín de cocina", para que en la explicación de los procesos evolutivos atendiéramos rigurosamente al orden relativo de los fenómenos fonéticos, para que, en fin, en la descripción de la sintaxis histórica no se diera un sólo paso sin aludir a los testimonios que la confirman.

La riqueza de información, la actualización bibliográfica, la valentía científica para adoptar criterios propios acerca de los temas más complejos de la historia de la lengua, su generosidad para rectificar cuando datos aportados por otros lo requería, pero también su seguridad para afirmase en sus juicios cuando los testimonios aportados eran irrebatibles, circulan por toda la obra histórica lapesiana. Por toda ella corre la sangre del espíritu. Es la erudición puesta al servicio del conocimiento del hombre. A Rafael Lapesa se le podría aplicar lo que él mismo dijo de Dámaso Alonso, ese "hermano mayor" en el afecto y en la filología del que se enorgulleció con frecuencia: "humano maestro de humanidades". Los estudios históricos de Rafael Lapesa son imprescindibles para quien se acerca al conocimiento de nuestro pasado histórico y lingüístico, pero lo serán también para quien advierta que en el uso de la lengua y en la constante evolución de sus variedades encontramos siempre al hombre concreto y a la comunidad en la que el hombre se realiza como ser histórico.

Algunos pensadores actuales nos están advirtiendo acerca del peligro que acecha a las ciencias humanas y sociales cuando se sustituye un lenguaje, en el que los no especialistas puedan reconocerse, por un metalenguaje que, lejos de estar al servicio de la precisión científica, sólo sirve para encastillar a quienes lo cultivan en supuestos círculos de saber, inaccesibles para los que no pertenecen a la propia secta. Creo que estas críticas tienen un fundamento sólido, como creo también que esas posiciones conducen al desprestigio final de las humanidades. Nadie más lejos de esa actitud que la de Rafael Lapesa. La 
documentación rigurosa se inserta en una prosa sobria, elegante, precisa. Él mismo nos dijo alguna vez a sus discípulos que su oratoria y su escritura era una constante lucha por la propiedad sintáctica. Son ya miles las páginas del maestro que atestiguan el éxito de su esfuerzo. No estaría de más, asimismo, que esto se tomara como ejemplo.

La imagen del profesor y científico riguroso que es Rafael Lapesa no debe ocultar la otra cara de su vida: el hombre afable con cuantos se acercaban a él, sensible ante la obra artística, virtuoso en el sentido que a esta palabra daban los clásicos. Poeta él mismo, vocación a la que no concedió el tiempo necesario, no podía por menos que manifestarlo en su concepción profunda de la enseñanza de la lengua: "Para terminar, dediquemos unos minutos a la misión principal del profesor de lengua y literatura: descubrir, revelar maravillas... (la cursiva es mía). La más noble función del lenguaje, la función representativa, consiste en reflejar, interpretar y ordenar el universo. Por lo tanto, el estudio de la lengua debe descubrirnos las maravillas existentes en su sistema, en el funcionamiento de éste y en su culminación en la creación literaria. Descubramos, mediante la literatura, la belleza natural y la belleza creada por el hombre... A través de la belleza literaria podremos ampliar horizontes de humanidad; comprender el pasado propio y ajeno; comprender también el presente propio y ajeno"96. Son palabras de un humanista de siempre, de un humanista de nuestro tiempo.

\footnotetext{
${ }^{96}$ Lapesa, Rafael, "Mi experiencia en la enseñanza del español y de la literatura”, cit., p. 492.
} 